AperTO - Archivio Istituzionale Open Access dell'Università di Torino

\title{
Biodiversity of wood-decay fungi in Italy
}

\section{This is the author's manuscript}

Original Citation:

Availability:

This version is available http://hdl.handle.net/2318/88396

since 2016-10-06T16:54:39Z

Published version:

DOI:10.1080/11263504.2011.633114

Terms of use:

Open Access

Anyone can freely access the full text of works made available as "Open Access". Works made available under a Creative Commons license can be used according to the terms and conditions of said license. Use of all other works requires consent of the right holder (author or publisher) if not exempted from copyright protection by the applicable law. 
This is the author's final version of the contribution published as:

A. Saitta; A. Bernicchia; S.P. Gorjón; E. Altobelli; V.M. Granito; C. Losi; D. Lunghini; O. Maggi; G. Medardi; F. Padovan; L. Pecoraro; A. Vizzini; A.M. Persiani. Biodiversity of wood-decay fungi in Italy. PLANT BIOSYSTEMS. 145(4) pp: 958-968.

DOI: $10.1080 / 11263504.2011 .633114$

The publisher's version is available at:

http://www.tandfonline.com/doi/abs/10.1080/11263504.2011.633114

When citing, please refer to the published version.

Link to this full text:

http://hdl.handle.net/2318/88396 


\title{
Biodiversity of wood-decay fungi in Italy
}

\author{
A. Saitta , A. Bernicchia , S. P. Gorjón, E. Altobelli , V. M. Granito , C. Losi , D. \\ Lunghini , O. Maggi , G. Medardi , F. Padovan , L. Pecoraro , A. Vizzini \& A. M. \\ Persiani
}

\begin{abstract}
Current knowledge about Italian wood-decay fungi (Basidiomycota and Ascomycota) is surveyed: 1582 taxa belonging to Ascomycota (341) and Basidiomycota (1241) have been reported, including 23 species new to science of Basidiomycota described from Italy within the last five years. Evaluating diversity of wood-decay fungi can provide a more accurate estimation of species richness for fungi which are an important functional component of ecosystems. Aphyllophoroid and Ascomycota species play an important role in habitat conservation and management. Sardinia, Sicily, the Alps and the Apennines are "hot spots" for wood-decay Basidiomycota in Italy.
\end{abstract}

Keywords: Ascomycota, Basidiomycota, biodiversity, Italy, wood-decay fungi,

\section{Introduction}

Dead wood constitutes a large part of total biomass of native forests, approximately $20-30 \%$ in mature forest ecosystems (Boddy \& Watkinson 1995 Boddy, L and Watkinson, S C. 1995. Wood decomposition, higher fungi, and their role in nutrient redistribution. Can J Bot, 73(Suppl. 1): S1377S1383. [CrossRef]), containing large pools of carbon and nutrients (Allen et al. 1997 Allen, R B, Clinton, P W and Davis, M R. 1997. Cation storage and availability along a Nothofagus forest development sequence in New Zealand. Can J For Res, 27: 323-330. [CrossRef], [Web of Science (®]). Studies carried out in the northern hemisphere have shown that logs host an extremely diverse range of fungi (e.g. Andersen \& Ryvarden 2001 Andersen, H and Ryvarden, L. 2001. Wood inhabiting fungi on Populus tremula. Windahlia, 24: 37-48. ; Boddy 2001 Boddy, L. 2001. Fungal community ecology and wood decomposition processes in angiosperms: From standing tree to complete decay of coarse woody debris. Ecol Bull, 49: 43-56. ; Edmonds \& Lebo 1998 Edmonds, R L and Lebo, D S. 1998. Diversity, production, and nutrient dynamics of fungal sporocarps on logs in an old-growth temperate rain forest, Olympic National Park, Washington. Can J For Res, 28: 665673. [CrossRef], [Web of Science (®]; Heilmann-Clausen \& Christensen 2005 Heilmann-Clausen, J and Christensen, M. 2005. Wood-inhabiting fungi in Danish beech-forests - conflicting diversity patterns and their implications in a conservation perspective. Biol Conserv, 122: 633-642. [CrossRef], [Web of Science $\left.{ }^{\circledR}\right]$ ). The presence of fungi in dead trees can also directly facilitate the colonization by species dependent on fungal mycelia or fruiting bodies, such as, for example many insects and their parasites (Komonen et al. 2000 Komonen, A, Penttila, R, Lindgren, M and Hanski, I. 2000. Forest fragmentation truncates a food chain based on an old-growth forest bracket fungus. Oikos, 90: 119-126. [CrossRef], [Web of Science ®]; Komonen 2003 Komonen, A. 2003. Distribution and abundance of insect fungivores in the fruiting bodies of Fomitopsis pinicola. Ann Zool Fenn, 40: 495-504. [Web of Science (]]; Jonsell \& Nordlander 2004 Jonsell, M and Nordlander, 
G. 2004. Host selection patterns in insects breeding in bracket fungi. Ecol Entomol, 29: 697-705.; Jonsell et al. 2005 Jonsell, M, Schroeder, M and Weslien, J. 2005. Saproxylic beetles in high stumps of spruce: Fungal flora important for determining the species composition. Scand J For Res, 20: 5462.) and other species of fungi (Niemelä et al. 1995 Niemelä, T, Renvall, P and Penttilä, R. 1995. Interactions of fungi at late stage of wood decomposition. Ann Bot Fen, 32: 141-152.). The structural diversity of forest ecosystems is clearly an important factor in maintaining forest biodiversity (Franklin et al. 2002 Franklin, J F, Spies, T A, Van Pelt, R, Carey, A B, Thornburgh, D ARae Berg, D. 2002. Disturbances and structural development of natural forest ecosystems with silvicultural implications, using Douglas_fir forests as an example. Forest Ecol Manag, 155: 399-423.; Lindenmayer et al. 2006 Lindenmayer, D B, Franklin, J F and Fischera, J. 2006. General management principles and a checklist of strategies to guide forest biodiversity conservation. Biol Conserv, 131: 433-445. [CrossRef], [Web of Science $\left.{ }^{\circledR}\right]$ ]). Wood-decay fungi are defined in this article as fungi which are found on or inhabiting woody substrata. The majority $(\sim 98 \%)$ of described fungal species are members of the dikarya clade, which includes the two phyla Ascomycota and Basidiomycota (James et al. 2006 James, T Y, Kauff, F, Schoch, C, Matheny, P B, Hofstetter, VCox, C J. 2006. Reconstructing the early evolution of Fungi using a six-gene phylogeny. Nature, 443: 818-822.). These will be analyzed in this article.

The evaluation of woody fungal biodiversity in Italy is still in progress. Ecological and distributive data on lignicolous macromycetes in Italy are not organized and still need a review analysis (Venturella et al. 2011 Venturella, G, Altobelli, E, Bernicchia, A, Di Piazza, S, Donnini, DGargano, M L. 2011. Fungal biodiversity and in situ conservation in Italy. Plant Biosyst, 145: 953-960. ). A positive step in reaching a more consistent organization of this information was the publication of the Check-list of Italian Fungi (Basidiomycota) by Onofri et al. (2005 Onofri, S, Bernicchia, A, Filipello Marchisio, V, Padovan, F, Perini, CRipa, C. 2005. Checklist dei funghi italiani-Checklist of Italian fungi, Basidiomycetes 1-380. Sassari C. Delfino ed) which includes a high number of wood-decay fungi, and the publication of other checklists (Bernicchia 2001 Bernicchia, A. 2001. A checklist of Corticioid, Polyporoid and Clavarioid fungi (Basidiomycetes) from the Emilia-Romagna region, Italy. Sydowia, 53: 1-33. ; Saitta et al. 2004 Saitta, A, Bernicchia, A and Venturella, G. 2004. Contributo alla conoscenza dei funghi lignicoli della Sicilia. Inform Bot Ital, 36: 192-202. ; Gorjón et al. 2006 Gorjón, S P, Bernicchia, A and Gibertoni, B T. 2006. Aphyllophoraceous wood-inhabiting fungi on Arbutus unedo in Italy. Mycotaxon, 98: 159-162.; Bernicchia et al. 2007b Bernicchia, A, Savino, E and Gorjón, S P. 2007b. Aphyllophoraceous wood-fungi on Pinus spp. in Italy. Mycotaxon, 101: 5-8.,c,d, 2008a,b), monographs (Polyporaceae s.1. by Bernicchia 2005 Bernicchia, A. 2005. Polyporaceae s.l. Fungi Europaei , 10. Ed, 808Alassio, Italy: Candusso. ; Corticiaceae s.l. by Bernicchia \& Gorjón 2010 Gorjón, S P and Bernicchia, A. 2010. The genus Dendrothele (Basidiomycota) in Italy, an update with notes on European species. Nova Hedwigia, 90: 233-250.; Ascomycota by Medardi 2006 Medardi, G. 2006. Ascomiceti d'Italia. Trento: A.M.B. Centro Studi Micologici, 454Trento: Associazione Micologica Bresadola. ) and papers (Venturella et al. 2007 Venturella, G, Bernicchia, A and Saitta, A. 2007. Contribution to the knowledge of diversity and distribution of lignicolous fungi from Sicily (southern Italy). Bocconea, 21: 291-295. ; Saitta \& Venturella 2010 Saitta, A and Venturella, G. 2010. La biodiversità dei funghi lignicoli in Sicilia. Micologia Italiana, 39: 12-17. ) concerning wood-decay fungi at both regional (Sicily, Sardinia and Emilia Romagna) and national levels. Besides these works, published data still need to be organized to better define the geographic pattern of this group of fungi, to demonstrate the ecological diversity within the group and to provide a more accurate estimation of the richness of these species in Italy. By using more recent published and unpublished data, the aim of this study is to contribute to the knowledge of wood-decay fungal biodiversity in Italy. The systematic arrangement in this article follows Kirk et al. (2008 Kirk, P M, Cannon, P F, Minter, D W and Stalpers, J A. 2008. Dictionary of the fungi. , 10th ed, 771UK: CABI Europe. ) and is also based on Blackwell et al. (2006 Blackwell, M, Hibbett, D S, Taylor, J W and Spatafora, J W. 2006. Research coordination networks: A phylogeny 
for kingdom Fungi (Deep Hypha). Mycologia, 98: 829-837.), James et al. (2006 James, T Y, Kauff, F, Schoch, C, Matheny, P B, Hofstetter, VCox, C J. 2006. Reconstructing the early evolution of Fungi using a six-gene phylogeny. Nature, 443: 818-822.) and Hibbett et al. (2007 Hibbett, D S, Binder, M, Bischoff, J F, Blackwell, M, Cannon, P FEriksson, O E. 2007. A higher-level phylogenetic classification of the Fungi. Mycol Res, 111: 509-547.).

\section{Ecology, systematics and distribution of wood-decay basidiomycetes in Italy}

The phylum Basidiomycota includes 16 classes, 52 orders, around 180 families and more than 31,000 species. Three subphyla are accepted, Agaricomycotina, Pucciniomycotina and Ustilaginomycotina (Kirk et al. 2008 Kirk, P M, Cannon, P F, Minter, D W and Stalpers, J A. 2008. Dictionary of the fungi. , 10th ed, 771UK: CABI Europe. ). In this study, we focus on two groups of wood-decay Basidiomycota: aphyllophoroid and non-aphyllophoroid. The aphyllophoroid group includes the Amylocorticiales K.H. Larss., Manfr. Binder \& Hibbett, Atheliales Jülich, Cantharellales Gäum., Corticiales K.H. Larss., Gloeophyllales Thorn, Gomphales Jülich, Hymenochaetales Oberw., Jaapiales Manfr. Binder, K.H. Larss. \& Hibbett, Polyporales Gäum., Thelephorales Corner ex Oberw., Trechisporales K.H. Larss. and some species belonging to the Agaricales Underw., Boletales E.-J. Gilbert and Russulales Kreisel ex P.M. Kirk, P.F. Cannon \& J.C. David. The non-aphyllophoroid group includes the Agaricales, Auriculariales J. Schröt., Cantharellales (not aphyllophoroid), Dacrymycetales Henn., Exobasidiales Henn., Helicobasidiales R. Bauer, Begerow, J.P. Samp., M. Weiss \& Oberw., Platygloeales R.T. Moore, Russulales Kreisel ex P.M. Kirk, P.F. Cannon \& J.C. David, Septobasidiales Couch ex Donk and Tremellales Fr.

The up-to-date total number of wood-decay Basidiomycota in Italy are 1241 taxa, which represent $78 \%$ of the fungal taxa listed in this work. Among them, 770 species are aphyllophoroid and 471 species are non-aphyllophoroid. This number is continuously changing and at least 23 taxa new to science of Basidiomycota have been described during the last five years in Italy.

The study of aphyllophoroid wood-inhabiting fungi enjoyed a golden period in Bresadola's time and the town of Trento became a datum point for all the contemporary mycologists. Later, this branch of mycological research was neglected for many decades. Only since the beginning of the 1980s of the last century this important and numerous group of fungi has been consistently studied again. Some mycologists, both academics and amateurs, kept alive the tradition begun by the Italian mycologists. Before 2005, we only have reprints listing observations of species from forests and reserves, although these cover many Italian regions. The aphyllophoroid fungi are included in a heterogeneous group composed generally of species ranging from resupinate to effuse-reflexed or pileate. During the last decades, with the introduction of the use of molecular data in taxonomy, the classification of the Aphyllophorales has dramatically changed. They form highly polyphyletic groups distributed over several families and orders among the homobasidiomycetes and most of them form basal clades among the major groups of Agaricales and Boletales (Binder \& Hibbett 2002 Binder, M and Hibbett, D S. 2002. Higher-level phylogenetic relationships of homobasidiomycetes (mushroom-forming fungi) inferred from four rDNA regions. Mol Phylogenet Evol, 22: 76-90; Hibbett et al. 2007 Hibbett, D S, Binder, M, Bischoff, J F, Blackwell, M, Cannon, P FEriksson, O E. 2007. A higherlevel phylogenetic classification of the Fungi. Mycol Res, 111: 509-547.; Larsson 2007 Larsson, K H. 2007. Re-thinking the classification of corticioid fungi. Mycol Res, 111: 1040-1063.; Binder et al. 2010 Binder, M, Larsson, K H, Matheny, P B and Hibbett, D S. 2010. Amylocorticiales ord. nov. and Jaapiales ord. nov.: Early diverging clades of Agaricomycetidae were dominated by corticioid forms. Mycologia, 102: 865-880.). 
In this article, we update the Italian data of aphyllophoroid wood-decay fungi to 770 species (online Appendix A) (456 corticioid, 265 polypores, 45 tomentelloid, 4 cyphelloid). They are distributed in the following orders: Agaricales (49), Amylocorticiales (8), Atheliales (42), Boletales (12), Cantharellales (43), Corticiales (15), Gloeophyllales (8), Gomphales (3), Hymenochaetales (137), Jaapiales (1), Polyporales (290), Russulales (89), Thelephorales (41), and Trechisporales (32).

The aphyllophoroid fungi include organisms with several ecological strategies. Most are saprobic while some are mycorrhizal (some tomentelloid species, the genera Albatrellus Gray and Boletopsis Fayod) or parasites. Among the polypores, it is worth highlighting some species because of their pathogenicity. These include Heterobasidion annosum (Fr.) Bref., H. abietinum Niemelä \& Korhonen, Inonotus hispidus (Bull.) P. Karst., Laetiporus sulphureus (Bull.) Murrill, Phaeolus schweintzii (Fr.) Pat., Phellinus chrysoloma (Fr.) Donk, P. tuberculosus (Baumg.) Niemelä, and Porodaedalea pini (Brot.) Murrill. Polypores and corticioid fungi colonize wood of a very wide range of plants during all decay stages; some are strictly specific and grow only on a single plant family or more rarely, on a sole species. They have been recorded mainly on the following substrata (online Appendix B): 267 species on Quercus spp., 238 on Pinus spp., 210 on Abies alba Mill., 186 on Fagus sylvatica L., 170 on Picea abies (L.) H. Karst., 70 on Castanea sativa Mill., 115 on Juniperus spp., 67 on Ulmus spp., 64 on Salix spp., 55 on Arbutus unedo L., 35 on Taxus baccata L.

More than 20 species new to science have been described during the last five years; they have been recorded in just a few Italian regions and several species have been described and successively recorded exclusively in Italy, such as Aleurodiscus ilexicola Bernicchia \& Ryvarden, Antrodia macrospora Bernicchia \& De Domincis, Antrodiella semistipitata Bernicchia \& Ryvarden, Botryobasidium sassofratinoense Bernicchia \& G. Langer, Byssomerulius pirottae (Bres.) Hjortstam, Ceriporia sulphuricolor Bernicchia \& Niemelä, Ceriporiopsis guidella Bernicchia \& Ryvarden, Cristinia artheniensis Baici \& Hjortstam, Echinodontium ryvardenii Bernicchia \& Piga, Fomitopsis labyrinthica Bernicchia \& Ryvarden, Hyphoderma etruriae Bernicchia, Lindtneria brevispora Bernicchia \& Gorjón, L. hydnoidea Bernicchia \& Ryvarden, Phanerochaete parvispora Sheng H. $\mathrm{Wu} \&$ Losi, Phlebia capitata Bernicchia \& Gorjón, Tomentellopsis pulchella K[otilde]ljalg \& Bernicchia and Vararia maremmana Bernicchia (Bernicchia 2005 Bernicchia, A. 2005. Polyporaceae s.l. Fungi Europaei, 10. Ed, 808Alassio, Italy: Candusso. ; Bernicchia \& Gorjón 2010 Gorjón, S P and Bernicchia, A. 2010. The genus Dendrothele (Basidiomycota) in Italy, an update with notes on European species. Nova Hedwigia, 90: 233-250.). Some species, described for the first time in Italy, have a distribution limited to certain Mediterranean or central European countries. Antrodia sandaliae Bernicchia \& Ryvarden has been collected only from dead branches of Arbutus unedo L. in Mediterranean forests of Sardinia and central-west Spain. Antrodiella ichnusana Bernicchia, Renvall \& Arras has been recorded also from Finland and France. Dendrothele wojewodae Pouzar was recorded in Italy, the Czech Republic and Ukraine (Gorjón \& Bernicchia 2010 Gorjón, S P and Bernicchia, A. 2010. The genus Dendrothele (Basidiomycota) in Italy, an update with notes on European species. Nova Hedwigia, 90: 233-250.). The new species Fibroporia bohemica Bernicchia, Vampola \& Prodi has been recently described morphologically and on a molecular basis, using specimens previously ascribed to $F$. radiculosa (Peck.) Gilbn. \& Ryvarden (Bernicchia et al. in press); so far, it is known from Bohemia in the Czech Republic and the Italian Alpes. Lindtneria panphyliensis Bernicchia \& M.J. Larsen has a well-documented distribution in Czech Republic, France, Italy and UK. Fibroporia citrina (Bernicchia \& Ryvarden) Bernicchia \& Ryvarden, Hyphoderma crustulinum (Bres.) Nakasone, Neolentiporus squamosellus (Bernicchia \& Ryvarden) Bernicchia \& Ryvarden, Phellinus juniperinus Bernicchia \& S. Curreli and P. rosmarini Bernicchia have also been recorded from France.

Among the group of species sharing a Mediterranean distribution and thus penetrating only into the warmer European areas the following are present in Italy: Acanthophysellum dextrinoideocerussatum 
Manjón, M.N. Blanco \& G. Moreno, Botryobasidium asperulum (D.P. Rogers) Boidin, Byssomerulius hirtellus (Burt) Parmasto, Ceriporia camaresiana (Bourdot \& Galzin) Bondartsev \& Singer, C. griseoviolascens M. Pieri \& B. Rivoire, Corticium meridioroseum Boidin \& Lanq., Dendrophora versiformis (Berk. \& M.A. Curtis) Chamuris, Duportella malenconii (Boidin \& Lanq.) Hjortstam, Hyphoderma malençonii (Manjón \& G. Moreno) Manjón, G. Moreno \& Hjortstam, Hyphodermella rosae (Bres.) Nakasone, Hexagonia nitida Durieu \& Mont., Inocutis tamaricis (Pat.) Fiasson \& Niemelä, Lenzites warnieri Mont. \& Durieu, Lenzitopsis oxycedri Malençon \& Bertault, Oligoporus inocybe (A. David \& Malençon) Ryvarden \& Gilb., Peniophora meridionalis Boidin, Phanerochaete aculeata Hallenb., P. martelliana (Bres.) J. Erikss. \& Ryvarden, P. juniperinus, $P$. rosmarini, Perenniporia meridionalis Decock \& Stalpers, Polyporus meridionalis (A. David) H. Jahn, Skeletocutis percandida (Malençon \& Bertault) Jean Keller, Stereum reflexulum D.A. Reid, Trametes junipericola Manjón, G. Moreno \& Ryvarden and Vuilleminia pseudocystidiata Boidin, Lanq. \& Gilles. A few species show a surprising distribution. Xanthoporus syringae (Parmasto) Audet, a species typically known from Scandinavia growing on Syringa vulgaris, has been collected in a mixed Picea and Alnus forest in north Italy. Fibricium gloeocystidiatum Rajchenb. has been described from the Andean Patagonian forests growing on the endemic conifer Austrocedrus chilensis (D. Don) Pic. Serm. \& Bizzarri and was collected in Sardinia on dead leaves of Osmunda regalis L. (Arras et al. 2007 Arras, L, Bernicchia, A and Piga, A. 2007. Fibricium gloeocystidiatum (Polyporales, Basidiomycetes) new to Europe. Mycotaxon, 100: 342-347. ). Dendrothele tetracornis Boidin \& Duhem is present in some Scandinavian countries and in two Mediterranean ones, Italy and France. Gyrodontium sacchari (Spreng.) Hjortstam, recorded from Sardinia is the only European collection while its main distributional pattern is Central and South America. Trechispora clancularis (Park.-Rhodes) K.H. Larss., known in Brasil and Tanzania, is now recorded in a very small number of European countries and in two Italian regions. Some corticioid and polyporoid species recently collected (Bernicchia pers. comm.), have such peculiar microscopic characteristics as to be undoubtedly new species and they will be described in further publications.

Most non-aphyllophoroid Basidiomycota belong to the order Agaricales. More than 13,000 species representing 413 genera and 33 families have been described (Kirk et al. 2008 Kirk, P M, Cannon, P F, Minter, D W and Stalpers, J A. 2008. Dictionary of the fungi. , 10th ed, 771UK: CABI Europe. ). Most lignicolous species of the Agaricales are white rot agents. The production of basidiomata on living trees or rotting wood is not necessarily indicative of saprotrophic nutrition. Some ectomycorrhizal Agaricales may also produce basidiomata on rotten wood. Recent phylogenetic research has shown that Singer's Agaricales sensu stricto (Singer 1986 Singer, R. 1986. The Agaricales in modern taxonomy. , 4th ed, Koenigstein: Koeltz Scientific Book. ) roughly corresponds to the euagarics clade (Hibbett et al. 1997 Hibbett, D S, Grimaldi, D and Donoghue, M J. 1997. Fossil mushrooms from Cretaceous and Miocene ambers and the evolution of homobasidiomycetes. Am J Bot, 84: 981-991.; Moncalvo et al. 2000 Moncalvo, J M, Lutzoni, F, Rehener, S A, Johnson, J and Vilgalys, R. 2000. Phylogenetic relationships of agaric fungi based on nuclear large subunit ribosomal DNA sequences. Syst Biol, 49: 278-305., 2002). However, molecular data have shown that an overemphasis on spore print color, basidiome developmental pattern and some anatomical and cytological traits has led to the establishment of many artificial groups, while some cyphelloid, aphyllophoroid and gasteroid fungi should be included. Hibbett et al. (1997 Hibbett, D S, Grimaldi, D and Donoghue, M J. 1997. Fossil mushrooms from Cretaceous and Miocene ambers and the evolution of homobasidiomycetes. Am J Bot, 84: 981-991.) and Hibbett (2004 Hibbett, D S. 2004. Trends in morphological evolution in homobasidiomycetes. Systematic Biol, 53: 889-903.), using nuclear and mitochondrial ribosomal DNA sequences of representatives of agarics, aphyllophoroid and gasteroid fungi (i.e. gilled, non-gilled agarics and puffballs) have shown that basidiome form and hymenophore type are not reliable phylogenetic markers. Phylogenetic analyses focused on Agaricales (euagarics clade) (Moncalvo et al. 2000 Moncalvo, J M, Lutzoni, F, Rehener, S A, Johnson, J and Vilgalys, R. 2000. Phylogenetic relationships of agaric fungi based on nuclear large 
subunit ribosomal DNA sequences. Syst Biol, 49: 278-305., 2002) have pointed out that some traditional taxonomic groups are artificial (for example Cortinariaceae, Tricholomataceae, Strophariaceae, Hygrophoraceae, Clitocybe, Omphalina and Marasmius), revealing 117 monophyletics clades. Some non-gilled resupinate, cyphelloid, and gasteroid taxa were classified as Agaricales (e.g. Peintner et al. 2001 Peintner, U, Bougher, N L, Castellano, M, Moncalvo, M, Moser, MTrappe, J. 2001. Multiple origins of sequestrate fungi related to Cortinarius (Cortinariaceae). Am $J$ Bot, 88: 2168-2179.; Binder \& Bresinsky 2002 Binder, M and Bresinsky, A. 2002. Derivation of a polymorphic lineage of Gasteromycetes from boletoid ancestors. Mycologia, 94: 85-98.; Bodensteiner et al. 2004 Bodensteiner, P, Binder, M, Moncalvo, J-M, Agerer, R and Hibbett, D S. 2004. Phylogenetic relationships of cyphelloid homobasidiomycetes. Mol Phylogenet Evol, 33: 501515.; Larsson et al. 2004 Larsson, K H, Larsson, E and K[otilde]ljalg, U. 2004. High phylogenetic diversity among corticioid basidiomycetes. Mycol Res, 108: 983-1002.; Binder et al. 2005 Binder, M, Hibbett, D S, Larsson, K H, Larsson, E, Langer, E and Langer, G. 2005. The phylogenetic distribution of resupinate forms across the major clades of mushroom-forming fungi (Homobasidiomycetes). Syst Biodivers, 3: 113-157.; Matheny \& Bougher 2006a Matheny, P B and Bougher, N L. 2006a. The new genus Auritella from Africa and Australia (Inocybaceae, Agaricales): Molecular systematics, taxonomy and historical biogeography. Mycol Prog, 5: 2-17.; Larsson 2007 Larsson, K H. 2007. Re-thinking the classification of corticioid fungi. Mycol Res, 111: 1040-1063.).

The most recent phylogenetic analysis of Agaricales was conducted by Matheny et al. (2006b Matheny, P B, Curtis, J C, Hofstter, V, Aime, M C, Moncalvo, J MGe, Z W. 2006b. Major clades of Agaricales: A multi-locus phylogenetic overview. Mycologia, 98: 982-995.) using a multigenic approach on 146 genera and 238 species. Bayesian analysis recognized six monophyletic groups which were named as Agaricoid, Tricholomatoid, Marasmioid, Pluteoid, Hygrophoroid and Plicaturopsidoid clades. According to Hibbett et al. (2007 Hibbett, D S, Binder, M, Bischoff, J F, Blackwell, M, Cannon, P FEriksson, O E. 2007. A higher-level phylogenetic classification of the Fungi. Mycol Res, 111: 509-547.) and to Matheny et al. (2006b Matheny, P B, Curtis, J C, Hofstter, V, Aime, M C, Moncalvo, J MGe, Z W. 2006b. Major clades of Agaricales: A multi-locus phylogenetic overview. Mycologia, 98: 982-995.), the order Agaricales belongs to the subclass Agaricomycetidae, along with the Atheliales and Boletales.

The total number of wood-decay non-aphyllophoroid taxa in Italy is 471 (online Appendix C), belonging to the orders Agaricales (351 taxa), Auriculariales (36), Dacrymycetales (14), Tremellales (14), Cantharellales (11), Polyporales (9), Russulales (8), Boletales (8), Gloeophyllales (4), Gomphales (4), Exobasidiales (3), Platigloeales (6), Septobasidiales (2) and Geastrales (1). Genera with higher numbers of taxa are Mycena (Pers.) Roussel (56), Pluteus Fr. (34), Pholiota (Fr.) P. Kumm. (24), Psathyrella (Fr.) Quél. (17), Crepidotus (Fr.) Staude (16), Marasmiellus Murrill (11), Exidia Fr. (10), Gymnopilus P. Karst. (10), Tremella Pers. (10), and Dacrymyces Nees (9).

Three species new to the science have been described during the last few years, Crinipellis pedemontana A. Vizzini, Antonín \& Noordel. (Vizzini et al. 2007 Vizzini, A, Antonin, V and Noordeloos, M E. 2007. Crinipellis pedemontana sp. nov. (Agaricomycetes), a new basidiomycete from Italy. Mycologia, 99: 786-791.), Gymnopilus maritimus Contu, Guzm.-Dáv., A. Ortega \& Vizzini (Guzmán-Dávalos et al. 2009 Guzmán-Dávalos, L, Contu, M, Ortega, A, Vizzini, A and Herrera, M. 2009. A new species of Gymnopilus (Basidiomycota, Agaricales) from coastal sand dunes of northern Sardinia. Mycol Prog, 8: 195-205.) and Gymnopus inexpectatus Consiglio, Vizzini, Antonín \& Contu (Vizzini et al. 2008 Vizzini, A, Consiglio, G, Antonin, V and Contu, M. 2008. A new species within the Gymnopus dryophilus complex (Agaricomycetes, Basidiomycota) from Italy. Mycotaxon, 105: 43-52.). Several species show a restricted national and European distribution. These include Baeospora myriadophylla (Peck) Singer, Buchwaldoboletus lignicola (Kallenb.) Pilát, Chaetocalathus craterellus (Durieu \& Lév.) Singer, Cheimonophyllum candidissimum (Berk. \& 
Curt.) Singer, Chromosera cyanophylla (Fr.) Redhead, C. subbulbipes Murrill, Chrysomphalina chrysophylla (Fr.) Clémençon, C. strombodes (Berk. \& Mont.) Clémençon, Cleistocybe pleurotoides (J. Favre) Vizzini (Vizzini 2009 Vizzini, A. 2009. Due nuove combinazioni nel genere Cleistocybe (Basidiomycota, Agaricomycetes), con validazione di Hygrophorus pleurotoides. Micologia $e$ Vegetazione Mediterr, 24: 95-98. ), Clitocybe truncicola (Peck) Sacc., Clitopilus hobsonii (Berk. \& Broome) P.D. Orton, C. rhodophyllus (Bres.) Singer, Ammirati \& Norvell, Coprinopsis strossmayeri Schulzer, Crepidotus cinnabarinus Peck, C. roseoornatus Pöder \& E. Ferrari, C. pedemontana, $C$. sardoa Candusso, Cystoderma subvinaceum A.H. Sm., Flammulina fennae Bas, G. maritimus, G. purpureosquamulosus Høil. (Guzmán-Dávalos et al. 2008 Guzmán-Dávalos, L, Contu, M, Ortega, A, Vizzini, A, Herrera, M, Ovrebo, CRodríguez, A. 2008. New morphological and molecular data on Gymnopilus purpureosquamulosus and its phylogenetic relationships among similar species. Sydowia, 60: 41-56.), Haasiella venustissima (Fr.) Kotl. \& Pouzar, Heliocybe sulcata (Berk.) Redhead \& Ginns, Hemistropharia albocrenulata (Peck) Jacobsson \& E. Larss., Hydropus atramentosus (Kalchbr.) Kotl. \& Pouzar, H. trichoderma (Joss.) Singer, Marasmiellus virgatocutis Robich, Esteve-Rav. \& G. Moreno, Mycetinis epidryas (Kühner) Antonín \& Noordel., Phaeomarasmius rimulincola (Rabenh.) P.D. Orton, Pholiota henningsii (Bres.) P.D. Orton, P. jahnii Tjall.-Beuk. \& Bas, P. subochracea (A.H. Sm.) A.H. Sm. \& Hesler, P. tubercolosa (Schaeff.:Fr.) P. Kumm., Pleurocybella porrigens (Pers.) Singer, Pluteus aurantiorugosus (Trog) Sacc., Rhodotus palmatus (Bull.:Fr.) Maire, Simocybe maritima (Bon) Bon, S. rubi (Berk.) Singer, Sparassis brevipes Krombh., Trichocybe puberula (Kuyper) Vizzini (Vizzini et al. 2010), and Tricholomopsis flammula Métrod.

Analysis of available data on distribution of wood-decay basidiomycetes in Italy suggests that some regions are very well explored while others such as the Valle d'Aosta, Umbria, Marche and Molise are poorly investigated and further studies and inventorial field work are needed. It is not possible to establish a conclusion about the distribution of the biodiversity due to the fragmentary survey.

\section{Candidate species included in the draft European red list}

Taking into account their distribution and ecological value, a significant number of these species, can be considered for inclusion in the draft European red list.

Of the wood-decay Basidiomycota (online Appendix D) 194 species are among the 1644 candidates for the European red list (http://www.wsl.ch/eccf/). Among them, the following species, because of their environmental importance and rarity in Italy, should be included in the future European red list: Aleurodiscus ilexicola, Amphinema diadema K.H. Larss. \& Hjortstam, Amyloathelia amylacea (Bourdot \& Galzin) Hjortstam \& Ryvarden, Antrodia albobrunnea (Romell) Ryvarden, A. alpina (Litsch.) Gilb. \& Ryvarden, A. pulvinascens (Pilát) Niemelä, A. sandaliae, Antrodiella ichnusana, Atheloderma mirabile Parmasto, B. myriadophylla, Botryobasidium robustius Pouzar \& Hol.-Jech., Ceriporia alachuana (Murrill) Hallenb., C. alba M. Pieri \& B. Rivoire, C. sulphuricolor, Ceriporiopsis guidella, C. cyanophylla, Clitocybe subbulbipes, C. truncicola, Coprinus strossmayeri, C. cinnabarinus, C. roseo-ornatus, Crinipellis sardoa, Crustoderma longicystidiatum (Litsch.) Nakasone, Cystoderma subvinaceum, Dendrothele amygdalispora Hjortstam, D. dryina (Pers.) P.A. Lemke, Dentipellis fragilis (Pers.) Donk, E. ryvardenii, Fomitopsis labyrinthica, H. venustissima (Fr.) Kotl. \& Pouzar, Hjortstamia crassa (Lév.) Boidin \& Gilles, Hyphoderma etruriae, Hypochnella violacea Auersw. ex J. Schröt., Inonotus andersonii (Ellis \& Everh.) Cerný, Laurilia sulcata (Burt) Pouzar, Lenzitopsis oxycedri, Lindtneria flava Parmasto, Odonticium helgae Hjortstam \& Ryvarden, Oligoporus simanii (Pilát) Bernicchia, Peniophora tamaricicola Boidin \& Malençon, Peniophorella guttulifera (P. Karst.) K.H. Larss., Phellinus rimosus (Berk.) Pilát, Ramaricium alboochraceum (Bres.) Jülich, Scotomyces subviolaceus (Peck) Jülich, Steccherinum robustius (J. Erikss. \& S. Lundell), Trametes junipericola, Trechispora kavinioides de Vries, Trichaptum laricinum (P. Karst.) 
Ryvarden, Vuilleminia megalospora Bres., and V.pseudocystidiata, Lanq. \& Gilles. In addition, there are some very rare and interesting species absent from the preliminary list, including Chaetoderma luna (Romell ex D.P. Rogers \& H.S. Jacks.) Parmasto, C. candidissimum, Dendrothele nivosa (Berk. \& M.A. Curtis ex Höhn. \& Litsch.) P.A. Lemke, Dendrothele wojewodae, F. fennae, Lindtneria panphyliensis, $M$. virgatocutis, $P$. porrigens and Vararia maremmana.

\section{Focal species for habitat conservation}

Given the importance of fungi in ecosystem processes, several studies have suggested use of fungi as focal species, or indicators of ecological continuity in forest ecosystems worldwide (e.g. SverdrupThygeson \& Lindenmayer 2003 Sverdrup-Thygeson, A and Lindenmayer, D B. 2003. Ecological continuity and assumed indicator fungi in boreal forest: The importance of the landscape matrix. Forest Ecol Manag, 174: 353-363.; Blasi et al. 2010 Blasi, C, Marchetti, M, Chiavetta, U, Aleffi, M, Audisio, PAzzella, M M. 2010. Multi-taxon and forest structure sampling for identification of indicators and monitoring of old growth forest. Plant Biosyst, 144: 160-170.).

A group of species growing on specific endangered substrata are the most useful way to drive the conservation of forest ecosystems. In Italy, many interesting and rare fungal species are linked to a specific substratum and can be used, as usually happens for mammals or birds, as "umbrella species", which provide for conservation of the entire ecosystem.

A significant number of Basidiomycota were found in plant communities included in the priority Habitats of Annex I of the Directive 92/43/EEC and its interpretation manual for Italy (Blasi et al. 2007 Blasi, C, Boitani, L, La Posta, S, Manes, F and Marchetti, M. 2007. "Biodiversity in Italy". In Contribution to the national biodiversity strategy, 460Roma: Palombi \& Partner S.r.L. ) and most of these belong to the aphyllophoroid group. The most significant habitats for their conservation are "Endemic forests with Juniperus spp. (*9560)" "Quercus suber forests (9330)", "Quercus ilex and Quercus rotundifolia forests (9340)", "Alpine Larix decidua and/or Pinus cembra forests (9420)" and "Apennine beech forests with Abies alba and beech forests with Abies nebrodensis (*9220)".

The cases of juniper and cork oak forests are highlighted as follow. Old Sardinian juniper (Juniperus phoenicea L. and J. oxycedrus L.) forests very often are selective substrata for very rare species such as E. ryvardenii, Hyphoderma etruriae, Lenzitopsis oxycedri, Neolentiporus squamosellus, Piloporia sajanensis (Parmasto) Niemelä and Trametes junipericola. Most species associated with ancient juniper forests occur in the Urzulei-Piraonni-Orgosolo-Lanaittu area, where some outstanding examples have been recorded. Juniper trees are an irreplaceable substratum, and for this reason survival of many wood-inhabiting Italian aphyllophoraceous species has become uncertain. Many polypores restricted to old specimens of Juniperus L. follow the host genus wherever it occurs, with a scattered distributional pattern. They may therefore be considered threatened species, and old juniper trees should be protected (Bernicchia \& Ryvarden 1988 Bernicchia, A and Ryvarden, L. 1988. Aleurodiscus ilexicola Bernicchia \& Ryvarden sp. nov. from Sardinia. Mycol Helv, 3: 83-88. ).

Mediterranean oak forests and shrublands are fragile ecosystems and some aphyllophoroid species connected with these habitat need to be protected. A species growing specifically or preferentially on Quercus suber L., Odonticium flavicans, is a good indicator of cork oak forests which should be conserved.

\section{Hot spots for wood-decay Basidiomycota in Italy}


Some areas such as the Alps and the Apennines, present a notable diversity of polypores and corticioids. Several aphyllophoroid fungi have been recorded exclusively from the Alps. These include Antrodia alpina, Antrodiella semistipitata, A. serpula (P. Karst.) Spirin \& Niemelä, Asterodon ferruginosus Pat., Atheloderma mirabile, Athelopsis lembospora (Bourdot) Oberw., Ceratobasidium anceps (Bres. \& Syd.) H.S. Jacks., Dendrothele amygdalispora and Xanthoporus syringae. Some areas of the Alps show a high fungal diversity (Bernicchia 2005 Bernicchia, A. 2005. Polyporaceae s.l. Fungi Europaei , 10. Ed, 808Alassio, Italy: Candusso. ; Bernicchia \& Gorjón 2010 Gorjón, S P and Bernicchia, A. 2010. The genus Dendrothele (Basidiomycota) in Italy, an update with notes on European species. Nova Hedwigia, 90: 233-250.), for example "Val Casies", "Val d'Ultimo" and "Val di Genova" in the Trentino Alto-Adige Region. From the last of these, recently, Antrodiella semistipitata has been described as a species new to the science (Bernicchia et al. 2007a Bernicchia, A, Ryvarden, L and Gibertoni, B T. 2007a. Antrodiella semistipitata (Basidiomycetes, Polyporales) a new species from Italy. Mycotaxon, 99: 231-237.). Some species have been exclusively recorded from the Apennines. The "Sasso Fratino" Reserve, for example, is a very interesting area for aphyllophoroid fungi, with two endemic polypores, Ceriporiopsis guidella (Bernicchia \& Ryvarden 2003 Bernicchia, A and Ryvarden, L. 2003. A new white-rot polypore from Italy. Mycotaxon, 88: 219-224.), Fomitopsis labyrinthica, one corticioid, Botryobasidium sassofratinoense Bernicchia \& G. Langer (Bernicchia et al. 2010 Bernicchia, A, Langer, G and Gorjón, S P. 2010. Botryobasidium sassofratinoense sp. nov. (Chantarellales, Basidiomycota) from Italy. Mycotaxon, 111: 403-409.), and several rare species such as Ceriporia herinkii Vampola, Crustomyces expallens (Bres.) Hjortstam, C. subabruptus (Bourdot \& Galzin) Jülich, Dentipellis fragilis, Hyphodontia latitans (Bourdot \& Galzin) Ginns \& M.N.L. Lefebvre, Parvobasidium cretatum (Bourdot \& Galzin) Jülich, Podofomes trogii (Fr.) Pouzar, Steccherinum robustius, and Xylodon nudisetus (Warcup \& P.H.B. Talbot) Hjortstam \& Ryvarden.

Sardinia and Sicily, the two major Italian islands, provide a refuge for many interesting species. Mediterranean forests and shrublands, typically consisting of densely or sparsely growing evergreen shrubs and trees, constitute a complex ecological system inhabited by some recently recognized species, many of them rare or very rare lignicolous fungi. In Sardinia, ancient juniper forests are a most remarkable ecosystem because of their many rare aphyllophoroid fungi already discussed. Some areas are notable for their fungal diversity. These include "Badde Salighes" (Bernicchia \& Ryvarden 1988 Bernicchia, A and Ryvarden, L. 1988. Aleurodiscus ilexicola Bernicchia \& Ryvarden sp. nov. from Sardinia. Mycol Helv, 3: 83-88. ), "Valle di Lanaittu", "Supramonte di Orgosolo" and "Urzulei" in Nuoro province. In Ogliastra province, there is the "Montarbu forest", the only known location of Antrodia sandaliae, and "Baccu Gerduri forest" where Antrodiella ichnusana can be found. Several species have been recorded on Juniperus spp.: E. ryvardenii, collected in Sardinia on Juniperus phoenicea and J. oxycedrus subsp. macrocarpa, Sibth. \& Sm., is very interesting because it is the first and so far the only known collection area of Echinodontium Ellis \& Everh. in Europe: all previously known species are North American or Asiatic (Bernicchia \& Piga 1998 Bernicchia, A and Piga, A. 1998. A new species of Echinodontium from Italy. Mycotaxon, 68: 483-491.). Piloporia sajanensis, recorded on J. oxycedrus subsp. oxycedrus L. is a boreal species, found in Scandinavia and central to eastern Russia. Its presence in Sardinia can be regarded as a relic from the last glacial period when ice reached most of central Europe and coniferous forest covered most of the higher areas in the Mediterranean region.

In Sicily, assessment of wood-decay fungi is still in progress and new distributional and ecological information is being acquired with the frequent discovery of previously unrecorded taxa. A huge number of species have been found in Quercus ilex L. and Q. suber woods. These include Ceriporia griseoviolascens, Gloeodontia columbiensis Burt ex Burds. \& Lombard, Lindtneria chordulata (D.P. Rogers) Hjortstam, Odonticium flavicans, Phellinus erectus A. David, Dequatre \& Fiasson, Phlebia nothofagi, Sarcodontia crocea (Schwein.) Kotl., Trechispora stevensonii (Berk. \& Broome) K.H. 
Larss., Vuilleminia coryli Boidin, Lanq. \& Gilles, and V.pseudocystidiata. The presence in Sicily of Oligoporus mappa (Overh. \& J. Lowe) Gilb. \& Ryvarden on Pinus halepensis Miller reforestation is noteworthy. Areas with high fungal diversity in Sicily are the "Madonie Park", "Ficuzza Wood-Rocca Busambra Reserve", "Monte Petroso" forest and "Nebrodi Park".

\section{Ecology, systematics and distribution of wood-decay ascomycetes}

Ascomycota is the largest phylum of kingdom Fungi and includes approximately 64,000 described species in 327 families of 68 orders (Kirk et al. 2008 Kirk, P M, Cannon, P F, Minter, D W and Stalpers, J A. 2008. Dictionary of the fungi. , 10th ed, 771UK: CABI Europe. ). It is characterized by production of meiospores in specialized sac-shaped meiosporangia (asci). The current classification of Ascomycota is based on a series of major phylogenetic studies carried out through the "Deep Hypha" and assembling the fungal tree of life (AFTOL) projects (Blackwell et al. 2006 Blackwell, M, Hibbett, D S, Taylor, J W and Spatafora, J W. 2006. Research coordination networks: A phylogeny for kingdom Fungi (Deep Hypha). Mycologia, 98: 829-837.; James et al. 2006 James, T Y, Kauff, F, Schoch, C, Matheny, P B, Hofstetter, VCox, C J. 2006. Reconstructing the early evolution of Fungi using a six-gene phylogeny. Nature, 443: 818-822.; Hibbett et al. 2007 Hibbett, D S, Binder, M, Bischoff, J F, Blackwell, M, Cannon, P FEriksson, O E. 2007. A higher-level phylogenetic classification of the Fungi. Mycol Res, 111: 509-547.), as well as other resources including Myconet (e.g. Eriksson 2006a Eriksson, O E. 2006a. Outline of Ascomycota - 2006. Myconet, 12: 1-82. ,b; http://fieldmuseum.org/myconet/printed.asp). In many instances, molecular and morphological data are congruent, but integration of these data has proved to be unfeasible in some cases, moreover a significant number of orders and many families have yet to have any members in them sequenced.

Currently, Ascomycota is divided into three monophyletic subphyla: Pezizomycotina, Saccharomycotina, and Taphrinomycotina. Pezizomycotina is the largest subphylum and includes the vast majority of filamentous, fruit-body-producing species (James et al. 2006 James, T Y, Kauff, F, Schoch, C, Matheny, P B, Hofstetter, VCox, C J. 2006. Reconstructing the early evolution of Fungi using a six-gene phylogeny. Nature, 443: 818-822.). Within this subphylum, in the Sordariomycetes clade there are fungi significant in a range of major ecologies including wood-decay (e.g. Xylariales) (Spatafora et al. 2006 Spatafora, J W, Sung, G H, Johnson, D, Hesse, C, O'Rourke, BSerdani, M. 2006. A five-gene phylogeny of Pezizomycotina. Mycologia, 98: 1018-1028.).

The decay of living trees, snags, fallen branches and logs is critical for the recycling of nutrients, and is effected primarily by fungi especially basidiomycetes and to a lesser extent ascomycetes and bacteria. Decayed wood within these structures houses a large portion of forest biodiversity (Berg et al. 1994 Berg, Å, Ehnström, B, Gustasson, L, Hallingbäck, T, Jonsell, M and Weslien, J. 1994. Threatened plant, animal, and fungus species in Swedish forests: Distribution and habitat associations. Conserv Biol, 8: 718-731.; Samuelsson et al. 1994 Samuelsson, J, Gustafsson, L and Ingelog, T. 1994. Dying and dead trees: A review of their importance for biodiversity, Uppsala, Sweden: Swedish Threatened Species Unit, Swedish National Environmental Protection Agency Report 4306. ; Franklin et al. 1997 Franklin, J F, Berg, D R, Thornburgh, D A and Tappeiner, J C. 1997. "Alternative silvicultural approaches to timber harvesting: Variable retention harvest systems". In Creating forestry for the 21st century: The science of ecosystem management, Edited by: Kohm, K A and Franklin, J F. 111-139. Washington, DC: Island Press. ; Butler et al. 2002 Butler, J, Alexander, K NA and Green, T. 2002. Decaying wood: An overview of its status and ecology in the United Kingdom and Continental Europe USDA Forest Service General Technical Report PSWGTR-181; Grove 2002 Grove, S J. 2002. Tree basal area and dead wood as surrogate indicators of 
saproxylic insect faunal integrity: A case study from the Australian lowland tropics. Ecol Indic, 1: 171-188.).

Many species of wood-decay fungi have preference for trees in a particular age class. In addition, the fungal communities in decomposing wood differ according to the particular decay classes (e.g. Heilmann-Clausen \& Boddy 2008; Fukasawa et al. 2011 Fukasawa, Y. 2011. Wood decomposing abilities of diverse lignicolous fungi on nondecayed beech wood. Mycologia, 103: 474-482[Web of Science $\left.{ }^{\circledR}\right]$ ). The occurrence of different fungal communities with different abilities to cause decay and with different ecological specialization defines the trophic fungal succession as a sequential colonization of the substratum. Fungal succession on wood is indirectly driven by wood properties (resource quality) and environmental factors (microclimate), and directly driven by fungal ecological strategies (pioneer, combative) (Boddy 1992 Boddy, L. 1992. "Development and function of fungal communities in decomposing wood". In The fungal community: Its organisation and role in the ecosystem. , 2nd ed, Edited by: Carroll, G C and Wicklow, D T. 749-782. New York, NY: MarcelDekker. , 2001). Many studies have reported that the Basidiomycota and Xylariaceae account for most lignocellulose decomposition in wood debris. Many authors (e.g. Worrall et al. 1997 Worrall, J J, Anagnost, S E and Zabel, R A. 1997. Comparison of wood decay among diverse lignicolous fungi. Mycologia, 89: 199-219.; Fukasawa et al. 2011 Fukasawa, Y. 2011. Wood decomposing abilities of diverse lignicolous fungi on nondecayed beech wood. Mycologia, 103: 474-482) have investigated wood decaying abilities of fungi using pure culture tests under laboratory conditions with the aim of understanding the role of fungi in wood decomposition in nature as well as the biological applications of these abilities. Weight losses caused by members of Ascomycota were generally moderate to low, but in the Xylariales and Sordariales approached 40\%. All ascomycetes that caused weight loss exceeding 2\% caused decay features characteristic of soft rot (Worrall et al. 1997 Worrall, J J, Anagnost, S E and Zabel, R A. 1997. Comparison of wood decay among diverse lignicolous fungi. Mycologia, 89: 199-219.). For several Ascomycota, such as some Xylariales, these authors reported the same complement of tested phenoloxidase activities (gallic and tannic acid, laccase, and peroxidase) as did typical white-rot fungi. White-rot fungi can progressively utilize all major cell wall components, including both the carbohydrates and the lignin.

Members of the Xylariaceae and Chaetomiaceae G. Winter and a few additional species showed other advanced decay features, including relatively high weight loss and lignin degrading ability. Fukasawa et al. (2011 Fukasawa, Y. 2011. Wood decomposing abilities of diverse lignicolous fungi on nondecayed beech wood. Mycologia, 103: 474-482) reported among the Xylariaceae [Hypoxylon fragiforme (Pers.) J. Kickx f. and Kretzschmaria deusta (Hoffm.) P.M.D. Martin], a greater weight loss for non-decayed beech wood than for intermediately and well-decayed wood. The weight losses were higher in intermediately or well-decayed wood in some anamorphic Ascomycota.

This first survey of wood-decay Ascomycota (excluding anamorphs) from Italy is based on species reported in the available literature which was largely contributed by Medardi (2006 Medardi, G. 2006. Ascomiceti d'Italia. Trento: A.M.B. Centro Studi Micologici, 454Trento: Associazione Micologica Bresadola. ), Saitta et al. (2004 Saitta, A, Bernicchia, A and Venturella, G. 2004. Contributo alla conoscenza dei funghi lignicoli della Sicilia. Inform Bot Ital, 36: 192-202. ) for Sicily, and unpublished data resulting from surveys carried out on coarse woody debris in the Cilento and Vallo di Diano National Park, (Campania) southern Italy (A. M. Persiani, personal communication). Collectively, these constitute a total of 341 taxa within the Pezizomycotina, with information about their distribution and substratum associations. It is far from exhaustive, but represents a good start for assessing the status of knowledge about Italian wood-decay Ascomycota diversity, for determining threats to that diversity, and promoting the most appropriate actions to be taken for its conservation within with forest ecosystems. The nomenclatural sources adopted were the Dictionary of the Fungi (Kirk et al. 2008 Kirk, P M, Cannon, P F, Minter, D W and Stalpers, J A. 2008. Dictionary of the 
fungi. , 10th ed, 771UK: CABI Europe. ) and IndexFungorum, the de facto global nomenclator for fungal names, http://www.indexfungorum.org/names/Names.asp.

The 341 species of wood-decay Ascomycota (Pezizomycotina) in Italy (i.e. only those species for which a woody substratum has been reported, belong in 24 orders, 57 families and 138 genera. The species are listed in the online Appendix E, in which are also reported their references published and/or unpublished in the case of research in progress. In respect of the biogeographic regions of Europe, and in the context of Alpine/Continental regions assigned to Italy, Lombardy is the most widely studied with 287 taxa, followed by Trentino and Veneto, with 85 and 71 taxa, respectively. In the Mediterranean region, Tuscany with 38 taxa, and Campania and Sicily, both with 36 taxa are the regions most studied. However, this dataset may reflect the distribution of researchers and of investigations carried out as well.

The best represented orders, as a percentage of the 341 species are: Helotiales Nannf. 30.5\%, Xylariales Nannf. 18.8\%, Pezizales J. Schröt. 12.3\%, Hypocreales Lindau 6.7\%, Diaporthales Nannf. 6.7\%, Pleosporales Luttr. ex M.E. Barr 5.0\% and Orbiliales Baral, O.E. Erikss., G. Marson \& E. Weber 3.5\%. The best represented families are: Xylariaceae 11.4\%, Helotiaceae Rehm 10.9\%, Hyaloscyphaceae Nannf. 7.9\%, Diatrypaceae Nitschke 6.7\%, Pezizaceae Dumort. 5.3\% and Dermateaceae Fr. 5.3\%. The best represented genera are: Peziza Fr. (14 taxa), Xylaria Hill ex Schrank (14), Orbilia Fr. (11), Scutellinia (Cooke) Lambotte (10), Hymenoscyphus Gray (9), Lachnellula P. Karst. (9), Hypocrea Fr. (8), Mollisia (Fr.) P. Karst. (8), Nectria (Fr.) Fr. (7), Lachnum Retz. (6), Hypoxylon Bull. (6), and Phaeohelotium Kanouse (6).

The high richness in species of Mollisia agrees with reports for boreal forests. In fact Mollisia includes species growing on plant debris as well as on decaying wood, and some are also obviously biotrophs. Kauserud et al. (2005 Kauserud, H, Lie, M, Stensrud, O and Ohlson, M. 2005. Molecular characterization of airborne fungal spores in boreal forests of contrasting human disturbance. Mycologia, 97: 1215-1224.) sampled fungal spores from air in three boreal forest sites and phylogenetic analyses were used to obtain a molecular characterization. Mollisia was the most abundant genus within Helotiales and was especially frequent in old-growth forest sites and lowest in the most disturbed clear-cut forests.

The results for the Pezizomycotina can also be correlated with various plant taxa (more than 50), including conifers, and broad-leaved, deciduous and evergreen shrubs, and trees. In most cases, these represent the most relevant vegetational aspects relative to the "forests, wood and scrubs" macro category of the Directive's habitats (92/43/EEC) and its interpretation manual for Italy (Blasi et al. 2007 Blasi, C, Boitani, L, La Posta, S, Manes, F and Marchetti, M. 2007. "Biodiversity in Italy". In Contribution to the national biodiversity strategy, 460Roma: Palombi \& Partner S.r.L. ).

The highest number of Pezizomycotina taxa was associated with Fagus sylvatica wood substrata (73), and in decreasing order Quercus spp. (70), Alnus spp. (42) and Populus spp. (36). Records from woody substrata of F. sylvatica and Quercus spp. will now be discussed.

In Europe, the southern limit of $F$. sylvatica is found in Italian beech forest stands and for this reason, these stands are of particular interest, particularly since, in Mediterranean Europe, forest exploitation has been going on for thousands of years, and during the 20th century a lot of deforestation took place (Gilg 2004 Gilg, O. 2004. Foréts a caractère naturel: Caractéristiques, conservation et suivi, 96Aten, Montpellier: Cahiers Techniques de l'ATEN, 74. ).

Of the 73 species reported as occurring on dead wood of $F$. sylvatica, around $70 \%$ are attributable to investigations in beech forests of protected areas in Italy (online Appendix F). With respect to some 
of these areas, two priority habitats indicated by the Habitat Directive (European Commission DG Environment, Nature and Biodiversity, 2003-Interpretation Manual of European Union Habitats - EUR25) are relevant, both phytogeographically and ecologically. They are: "Apennine beech forests with Taxus and Ilex" (*9210) for the PNCVD and "Apennine beech forests with Abies alba and beech forests with Abies nebrodensis" (*9220) for Sicily (Madonie Park).

Of the Pezizomycotina recorded on F. sylvatica dead wood, four genera are the most represented, each with four species: Hymenoscyphus calyculus (Sowerby) W. Phillips, H. imberbis (Bull.) Dennis, H. serotinus (Pers.) W. Phillips, H. sublateritius (Berk. \& Broome) Dennis, Hypocrea aureoviridis Plowr. \& Cooke, H. citrina (Pers.) Fr., H. gelatinosa (Tode) Fr., H. rufa (Pers.) Fr., Hypoxylon fragiforme, H. fuscum (Pers.) Fr., H. rubiginosum (Pers.) Fr., H. rutilum Tul. \& C. Tul., Xylaria hypoxylon (L.) Grev., X. juruensis Henn., X. longipes Nitschke, and X. polymorpha (Pers.) Grev. Diatrype Fr. is represented by three species: D. bullata (Hoffm.) Fr., D. disciformis (Hoffm.) Fr., and D. stigma (Hoffm.) Fr.

This survey is the first Italian contribution about species of Pezizomycotina associated with beech wood to highlight the key importance of dead wood for biodiversity in these forests and its availability to possible specific species' demand.

The occurrence of wood-inhabiting fungi can be considered as an indicator of the natural value of European beech forests, and some authors (e.g. Christensen et al. 2004 Christensen, M, HeilmannClausen, J, Walleyn, R and Adamcik, S. Wood-inhabiting fungi as indicators of nature value in European beech forests. EFI Proceedings No. 51. Edited by: Marchetti, M. pp.526Finland Joensuu: European Forest Institute. Monitoring and indicators of forest biodiversity in Europe e from ideas to operationality) have proposed a set of fungal indicator species, predominantly Basidiomycota, to be considered in setting conservation priorities in European beech forests.

In respect of the Pezizomycotina recorded on Quercus spp. dead wood (online Appendix G) four genera are strongly represented. Hypoxylon has five species: Hypoxylon fragiforme, $H$. fuscum, $H$. howeanum Peck, $H$. rubiginosum and $H$. rutilum. Mollisia has four species: M. cinerea (Batsch) P. Karst., M. discolor var. longispora Le Gal, M. ligni (Desm.) P. Karst., M. ramealis P. Karst. The genera Daldinia Ces. \& De Not. and Lachnum are both represented by three species: D. concentrica (Bolton) Ces. \& De Not., D. martinii M. Stadler, Venturella \& Wollw., D. raimundi M. Stadler, Venturella \& Wollw., L. bicolor (Bull.) P. Karst., L. brevipilosum Baral and L. virgineum (Batsch) P. Karst. Among Quercus species, Q. ilex is notable as representative of the Mediterranean sclerophyllous forests so widely characteristic of Italy. Prolonged exploitation of forests in Italy favors this species which is more adapted to xeric environments than deciduous Quercus species like $Q$. pubescens Willd. and $Q$. cerris $\mathrm{L}$. The highest number of taxa were recorded from $Q$. ilex (26) (online Appendix H), compared to 70 species for all species of Quercus combined.

Of the 341 species reported in this study, 20 (online Appendix I) appear in red lists of other European countries (http://www.wsl.ch/eccf/). Among those 20 species we wish to highlight Biscogniauxia mediterranea (De Not.) Kuntze, Hymenoscyphus monticola (Berk.) Baral and Chlorociboria aeruginosa (Oeder) Seaver ex C.S. Ramamurthi, Korf \& L.R. Batra, all on woody substrata of $F$. sylvatica and Quercus spp.

\section{Focal species for habitat conservation}

In Italy, an integrated research project has been carried out in the Cilento and Vallo di Diano National Park on broad-leaved forests with varying management histories (Burrascano et al. 2009 Burrascano, S, Rosati, L and Blasi, C. 2009. Plant species diversity in Mediterranean old-growth forests: A case 
study from central Italy. Plant Biosyst, 143: 190-200.). As part of this, the diversity of woodinhabiting fungi and beetles was also surveyed (Persiani et al. 2010 Persiani, A M, Audisio, P, Lunghini, D, Maggi, O, Granito, V MBiscaccianti, A B. 2010. Linking taxonomical and functional biodiversityof saproxylic fungi and beetles in broad-leaved forests in Southern Italy with varying management histories. Plant Biosyst, 144: 250-261.).

This project carried out multi-taxon and forest structure sampling to identify indicators and monitor (Blasi et al. 2010 Blasi, C, Marchetti, M, Chiavetta, U, Aleffi, M, Audisio, PAzzella, M M. 2010. Multi-taxon and forest structure sampling for identification of indicators and monitoring of old growth forest. Plant Biosyst, 144: 160-170.). Among other taxa, three Pezizomycotina, Ascocoryne cylichnium (Tul.) Korf, Xylaria polymorpha and Hymenoscyphus serotinus, were shown to be oldgrowth forest indicators, albeit with an only marginally significant indicator value, using the indicator species analysis (ISA) and the software PC-ORD 5 (McCune \& Mefford 2006 McCune, B and Mefford, M J. 2006. "PC-ORD. Multivariate analysis of ecological data". In Version 5.10, Gleneden Beach, OR, USA: MjM Software. ). Xylaria polymorpha was also considered to be an old-growth indicator species by Schmid and Helfer (1999 Schmid, H and Helfer, W. 1999. Die Bedeutung der Naturwaldreservate für den Pilzartenschutz. Seminarbericht der Natur-und Umweltschutzakademie des Landes Nordrhein-Westfalen (NUA), 4: 140-146. ) and Parmasto (2001 Parmasto, E. 2001. "Fungi as indicators of primeval and old-growth forests deserving protection". In Fungal conservation, issues and solutions, Edited by: Moore, D, Nauta, M N, Evans, S E and Rotheroe, M. 81-88. Cambridge, UK: Cambridge University Press.).

Referring to our dataset, all three are among the species associated with beech wood; their occurrence thus plays a vital role to indicate the natural value of Italian/European beech forests.

\section{Documenting and conserving Italian fungal biodiversity}

Mycology has a long tradition in Europe and hence knowledge of species, their distribution, ecology and status in Europe is the most extensive in the world. On this basis it would be feasible to analyze the status of European fungal diversity to establish conservation priorities for fungi as part of national and the European conservation priorities also applying IUCN red-listing priorities (Dahlberg \& Mueller 2011 Dahlberg, A and Mueller, G M. 2011. Applying IUCN red-listing criteria for assessing and reporting on the conservation status of fungal species. Fungal Ecol, 4: 147-162.). On the other hand, the large number of species, and in some cases, a lack of synergy between professional and amateur mycologists, has meant that, to date, this knowledge (particularly within anamorphic and teleomorphic ascomycetes) is low, compared with more well-known groups of species (Senn-Irlet et al. 2007 Senn-Irlet, B, Heilmann-Clausen, J, Genney, D R and Dahlberg, A. 2007. Guidance for conservation of macrofungi in Europe, 34Strasbourg: ECCF. ).

In Italy there are still limits to the knowledge of wood-decay Pezizomycotina impeding compilation of the regional and national level check-lists which would allow characterization of declining, rare and threatened populations. The set of data presented in this survey represents the first major contribution to the knowledge of the distribution of these species and their relationship with their substrata in Italy. We believe the present contribution will be useful at a European scale too.

According to the Ascomycete Conservation Specialist Group (http://www.cybertruffle.org.uk/ascos/index.htm) ascomycetes have been seriously overlooked in conservation while, at the same time, it is becoming clear that this largest single group of fungi may be adversely affected by human activities. We also hope for an increase in Italian research to determine the threats Pezizomycotina are facing and the development of long-term programs to assess the status of individual species. This will contribute to the conservation of fungi in Europe and will 
achieve the aims reported within the Convention on the conservation of European wildlife and natural habitats (Senn-Irlet et al. 2007 Senn-Irlet, B, Heilmann-Clausen, J, Genney, D R and Dahlberg, A. 2007. Guidance for conservation of macrofungi in Europe, 34Strasbourg: ECCF. ).

\section{References}

- Allen, R B, Clinton, P W and Davis, M R. 1997. Cation storage and availability along a Nothofagus forest development sequence in New Zealand. Can J For Res, 27: 323-330.

- Andersen, H and Ryvarden, L. 2001. Wood inhabiting fungi on Populus tremula. Windahlia, 24: $37-48$.

- Arras, L, Bernicchia, A and Piga, A. 2007. Fibricium gloeocystidiatum (Polyporales, Basidiomycetes) new to Europe. Mycotaxon, 100: 342-347.

- Berg, Å, Ehnström, B, Gustasson, L, Hallingbäck, T, Jonsell, M and Weslien, J. 1994. Threatened plant, animal, and fungus species in Swedish forests: Distribution and habitat associations. Conserv Biol, 8: 718-731.

- Bernicchia, A. 2001. A checklist of Corticioid, Polyporoid and Clavarioid fungi (Basidiomycetes) from the Emilia-Romagna region, Italy. Sydowia, 53: 1-33.

- Bernicchia, A. 2005. Polyporaceae s.l. Fungi Europaei, 10. Ed, 808Alassio, Italy: Candusso.

- Bernicchia, A, Arras, L, Piga, A and Ryvarden, L. 2008a. Biodiversity of Sardinian Aphyllophoraceous fungi. Synopsis Fungorum Fungiflora, Oslo, 25: 53-124.

- Bernicchia, A, Benni, A, Venturella, G, Gargano, M L, Saitta, A and Pérez Gorjón, S. 2008b. Aphyllophoraceous wood-inhabiting fungi on Quercus spp. in Italy. Mycotaxon, 104: 445448.

- Bernicchia, A and Gorjón, S P. 2010. Corticiaceae s.l. Fungi Europaei, 12. Ed, 1008Alassio, Italy: Candusso.

- Bernicchia, A, Gorjón, S P, Vampola, P, Ryvarden, L and Prodi, A. in press. A phylogenetic analysis of Antrodia s.l. based on nrDNA ITS sequences, with emphasis on rhizomorphic European species. Mycol Prog, : 8 (DOI: 10.1007/s11557-010-0732-z)

- Bernicchia, A, Langer, G and Gorjón, S P. 2010. Botryobasidium sassofratinoense sp. nov. (Chantarellales, Basidiomycota) from Italy. Mycotaxon, 111: 403-409.

- Bernicchia, A and Piga, A. 1998. A new species of Echinodontium from Italy. Mycotaxon, 68: 483-491.

- Bernicchia, A and Ryvarden, L. 1988. Aleurodiscus ilexicola Bernicchia \& Ryvarden sp. nov. from Sardinia. Mycol Helv, 3: 83-88.

- Bernicchia, A and Ryvarden, L. 2003. A new white-rot polypore from Italy. Mycotaxon, 88: 219-224.

- Bernicchia, A, Ryvarden, L and Gibertoni, B T. 2007a. Antrodiella semistipitata (Basidiomycetes, Polyporales) a new species from Italy. Mycotaxon, 99: 231-237.

- Bernicchia, A, Savino, E and Gorjón, S P. 2007b. Aphyllophoraceous wood-fungi on Pinus spp. in Italy. Mycotaxon, 101: 5-8.

- Bernicchia, A, Savino, E and Gorjón, S P. 2007c. Aphyllophoraceous wood-inhabiting fungi on Abies alba in Italy. Mycotaxon, 100: 185-188.

- Bernicchia, A, Venturella, G, Saitta, A and Gorjón, S P. 2007d. Aphyllophoraceous woodinhabiting fungi on Fagus sylvatica in Italy. Mycotaxon, 101: 229-232.

- Binder, M and Bresinsky, A. 2002. Derivation of a polymorphic lineage of Gasteromycetes from boletoid ancestors. Mycologia, 94: 85-98.

- Binder, M and Hibbett, D S. 2002. Higher-level phylogenetic relationships of homobasidiomycetes (mushroom-forming fungi) inferred from four rDNA regions. Mol Phylogenet Evol, 22: 76-90. 
- Binder, M, Hibbett, D S, Larsson, K H, Larsson, E, Langer, E and Langer, G. 2005. The phylogenetic distribution of resupinate forms across the major clades of mushroom-forming fungi (Homobasidiomycetes). Syst Biodivers, 3: 113-157.

- Binder, M, Larsson, K H, Matheny, P B and Hibbett, D S. 2010. Amylocorticiales ord. nov. and Jaapiales ord. nov.: Early diverging clades of Agaricomycetidae were dominated by corticioid forms. Mycologia, 102: 865-880.

- Blackwell, M, Hibbett, D S, Taylor, J W and Spatafora, J W. 2006. Research coordination networks: A phylogeny for kingdom Fungi (Deep Hypha). Mycologia, 98: 829-837.

- Blasi, C, Boitani, L, La Posta, S, Manes, F and Marchetti, M. 2007. "Biodiversity in Italy". In Contribution to the national biodiversity strategy, 460Roma: Palombi \& Partner S.r.L.

- Blasi, C, Marchetti, M, Chiavetta, U, Aleffi, M, Audisio, PAzzella, M M. 2010. Multi-taxon and forest structure sampling for identification of indicators and monitoring of old growth forest. Plant Biosyst, 144: 160-170.

- Boddy, L. 1992. "Development and function of fungal communities in decomposing wood". In The fungal community: Its organisation and role in the ecosystem. , 2nd ed, Edited by: Carroll, G C and Wicklow, D T. 749-782. New York, NY: Marcel-Dekker.

- Boddy, L. 2001. Fungal community ecology and wood decomposition processes in angiosperms: From standing tree to complete decay of coarse woody debris. Ecol Bull, 49: 43-56.

- Boddy, L and Watkinson, S C. 1995. Wood decomposition, higher fungi, and their role in nutrient redistribution. Can J Bot, 73(Suppl. 1): S1377-S1383.

- Bodensteiner, P, Binder, M, Moncalvo, J-M, Agerer, R and Hibbett, D S. 2004. Phylogenetic relationships of cyphelloid homobasidiomycetes. Mol Phylogenet Evol, 33: 501-515.

- Burrascano, S, Rosati, L and Blasi, C. 2009. Plant species diversity in Mediterranean oldgrowth forests: A case study from central Italy. Plant Biosyst, 143: 190-200.

- Butler, J, Alexander, K NA and Green, T. 2002. Decaying wood: An overview of its status and ecology in the United Kingdom and Continental Europe USDA Forest Service General Technical Report PSW-GTR-181

- Christensen, M, Heilmann-Clausen, J, Walleyn, R and Adamcik, S. Wood-inhabiting fungi as indicators of nature value in European beech forests. EFI Proceedings No. 51. Edited by: Marchetti, M. pp.526Finland Joensuu: European Forest Institute. Monitoring and indicators of forest biodiversity in Europe e from ideas to operationality

- Dahlberg, A and Mueller, G M. 2011. Applying IUCN red-listing criteria for assessing and reporting on the conservation status of fungal species. Fungal Ecol, 4: 147-162.

- Edmonds, R L and Lebo, D S. 1998. Diversity, production, and nutrient dynamics of fungal sporocarps on logs in an old-growth temperate rain forest, Olympic National Park, Washington. Can J For Res, 28: 665-673.

- Eriksson, O E. 2006a. Outline of Ascomycota - 2006. Myconet, 12: 1-82.

- Eriksson, O E. 2006b. Notes on ascomycete systematics. Nos 4299-4407. Myconet, 12: 83101.

- European Commission DG Environment, Nature and Biodiversity. 2003. Interpretation manual of european union habitats-EUR25, Bruxelles: European Commission DG Environment, Nature and Biodiversity.

- Franklin, J F, Berg, D R, Thornburgh, D A and Tappeiner, J C. 1997. "Alternative silvicultural approaches to timber harvesting: Variable retention harvest systems". In Creating forestry for the 21 st century: The science of ecosystem management, Edited by: Kohm, K A and Franklin, J F. 111-139. Washington, DC: Island Press.

- Franklin, J F, Spies, T A, Van Pelt, R, Carey, A B, Thornburgh, D ARae Berg, D. 2002. Disturbances and structural development of natural forest ecosystems with silvicultural implications, using Douglas_fir forests as an example. Forest Ecol Manag, 155: 399-423. 
- Fukasawa, Y. 2011. Wood decomposing abilities of diverse lignicolous fungi on nondecayed beech wood. Mycologia, 103: 474-482

- Gilg, O. 2004. Foréts a caractère naturel: Caractéristiques, conservation et suivi, 96Aten, Montpellier: Cahiers Techniques de l'ATEN, 74.

- Gorjón, S P and Bernicchia, A. 2010. The genus Dendrothele (Basidiomycota) in Italy, an update with notes on European species. Nova Hedwigia, 90: 233-250.

- Gorjón, S P, Bernicchia, A and Gibertoni, B T. 2006. Aphyllophoraceous wood-inhabiting fungi on Arbutus unedo in Italy. Mycotaxon, 98: 159-162.

- Grove, S J. 2002. Tree basal area and dead wood as surrogate indicators of saproxylic insect faunal integrity: A case study from the Australian lowland tropics. Ecol Indic, 1: 171-188.

- Guzmán-Dávalos, L, Contu, M, Ortega, A, Vizzini, A and Herrera, M. 2009. A new species of Gymnopilus (Basidiomycota, Agaricales) from coastal sand dunes of northern Sardinia. Mycol Prog, 8: 195-205.

- Guzmán-Dávalos, L, Contu, M, Ortega, A, Vizzini, A, Herrera, M, Ovrebo, CRodríguez, A. 2008. New morphological and molecular data on Gymnopilus purpureosquamulosus and its phylogenetic relationships among similar species. Sydowia, 60: 41-56.

- Heilmann-Clausen, J and Boddy, L. 2008. "Distribution patterns of wood-decay basidiomycetes at the landscape to global scale". In Ecology of saprotrophic basidiomycetes, Edited by: Boddy, L, Frankland, J C and van West, P. 263-275. UK: The British Mycological Society/Elsevier.

- Heilmann-Clausen, J and Christensen, M. 2005. Wood-inhabiting fungi in Danish beechforests - conflicting diversity patterns and their implications in a conservation perspective. Biol Conserv, 122: 633-642.

- Hibbett, D S. 2004. Trends in morphological evolution in homobasidiomycetes. Systematic Biol, 53: 889-903.

- Hibbett, D S, Binder, M, Bischoff, J F, Blackwell, M, Cannon, P FEriksson, O E. 2007. A higher-level phylogenetic classification of the Fungi. Mycol Res, 111: 509-547.

- Hibbett, D S, Grimaldi, D and Donoghue, M J. 1997. Fossil mushrooms from Cretaceous and Miocene ambers and the evolution of homobasidiomycetes. Am J Bot, 84: 981-991.

- James, T Y, Kauff, F, Schoch, C, Matheny, P B, Hofstetter, VCox, C J. 2006. Reconstructing the early evolution of Fungi using a six-gene phylogeny. Nature, 443: 818-822.

- Jonsell, M and Nordlander, G. 2004. Host selection patterns in insects breeding in bracket fungi. Ecol Entomol, 29: 697-705.

- Jonsell, M, Schroeder, M and Weslien, J. 2005. Saproxylic beetles in high stumps of spruce: Fungal flora important for determining the species composition. Scand J For Res, 20: 54-62.

- Kauserud, H, Lie, M, Stensrud, O and Ohlson, M. 2005. Molecular characterization of airborne fungal spores in boreal forests of contrasting human disturbance. Mycologia, 97: 1215-1224.

- Kirk, P M, Cannon, P F, Minter, D W and Stalpers, J A. 2008. Dictionary of the fungi. , 10th ed, 771UK: CABI Europe.

- Komonen, A. 2003. Distribution and abundance of insect fungivores in the fruiting bodies of Fomitopsis pinicola. Ann Zool Fenn, 40: 495-504.

- Komonen, A, Penttila, R, Lindgren, M and Hanski, I. 2000. Forest fragmentation truncates a food chain based on an old-growth forest bracket fungus. Oikos, 90: 119-126.

- Larsson, K H. 2007. Re-thinking the classification of corticioid fungi. Mycol Res, 111: 10401063.

- Larsson, K H, Larsson, E and K[otilde]ljalg, U. 2004. High phylogenetic diversity among corticioid basidiomycetes. Mycol Res, 108: 983-1002.

- Lindenmayer, D B, Franklin, J F and Fischera, J. 2006. General management principles and a checklist of strategies to guide forest biodiversity conservation. Biol Conserv, 131: 433-445. 
- Matheny, P B and Bougher, N L. 2006a. The new genus Auritella from Africa and Australia (Inocybaceae, Agaricales): Molecular systematics, taxonomy and historical biogeography. Mycol Prog, 5: 2-17.

- Matheny, P B, Curtis, J C, Hofstter, V, Aime, M C, Moncalvo, J MGe, Z W. 2006b. Major clades of Agaricales: A multi-locus phylogenetic overview. Mycologia, 98: 982-995.

- McCune, B and Mefford, M J. 2006. "PC-ORD. Multivariate analysis of ecological data". In Version 5.10, Gleneden Beach, OR, USA: MjM Software.

- Medardi, G. 2006. Ascomiceti d'Italia. Trento: A.M.B. Centro Studi Micologici, 454Trento: Associazione Micologica Bresadola.

- Moncalvo, J M, Lutzoni, F, Rehener, S A, Johnson, J and Vilgalys, R. 2000. Phylogenetic relationships of agaric fungi based on nuclear large subunit ribosomal DNA sequences. Syst Biol, 49: 278-305.

- Moncalvo, J M, Vilgalys, R, Redhead, S A, Johnson, J E, James, T YAime, M C. 2002. One hundred and seventeen clades of euagarics. Mol Phylogenet Evol, 23: 357-400.

- Niemelä, T, Renvall, P and Penttilä, R. 1995. Interactions of fungi at late stage of wood decomposition. Ann Bot Fen, 32: 141-152.

- Onofri, S, Bernicchia, A, Filipello Marchisio, V, Padovan, F, Perini, CRipa, C. 2005. Checklist dei funghi italiani-Checklist of Italian fungi, Basidiomycetes 1-380. Sassari C. Delfino ed

- Parmasto, E. 2001. "Fungi as indicators of primeval and old-growth forests deserving protection”. In Fungal conservation, issues and solutions, Edited by: Moore, D, Nauta, M N, Evans, S E and Rotheroe, M. 81-88. Cambridge, UK: Cambridge University Press.

- Peintner, U, Bougher, N L, Castellano, M, Moncalvo, M, Moser, MTrappe, J. 2001. Multiple origins of sequestrate fungi related to Cortinarius (Cortinariaceae). Am J Bot, 88: 2168-2179.

- Persiani, A M, Audisio, P, Lunghini, D, Maggi, O, Granito, V MBiscaccianti, A B. 2010. Linking taxonomical and functional biodiversityof saproxylic fungi and beetles in broadleaved forests in Southern Italy with varying management histories. Plant Biosyst, 144: 250261.

- Saitta, A, Bernicchia, A and Venturella, G. 2004. Contributo alla conoscenza dei funghi lignicoli della Sicilia. Inform Bot Ital, 36: 192-202.

- Saitta, A and Venturella, G. 2010. La biodiversità dei funghi lignicoli in Sicilia. Micologia Italiana, 39: 12-17.

- Samuelsson, J, Gustafsson, L and Ingelog, T. 1994. Dying and dead trees: A review of their importance for biodiversity, Uppsala, Sweden: Swedish Threatened Species Unit, Swedish National Environmental Protection Agency Report 4306.

- Schmid, H and Helfer, W. 1999. Die Bedeutung der Naturwaldreservate für den Pilzartenschutz. Seminarbericht der Natur-und Umweltschutzakademie des Landes Nordrhein-Westfalen (NUA), 4: 140-146.

- Senn-Irlet, B, Heilmann-Clausen, J, Genney, D R and Dahlberg, A. 2007. Guidance for conservation of macrofungi in Europe, 34Strasbourg: ECCF.

- Singer, R. 1986. The Agaricales in modern taxonomy. , 4th ed, Koenigstein: Koeltz Scientific Book.

- Spatafora, J W, Sung, G H, Johnson, D, Hesse, C, O'Rourke, BSerdani, M. 2006. A five-gene phylogeny of Pezizomycotina. Mycologia, 98: 1018-1028.

- Sverdrup-Thygeson, A and Lindenmayer, D B. 2003. Ecological continuity and assumed indicator fungi in boreal forest: The importance of the landscape matrix. Forest Ecol Manag, 174: 353-363.

- Venturella, G, Altobelli, E, Bernicchia, A, Di Piazza, S, Donnini, DGargano, M L. 2011. Fungal biodiversity and in situ conservation in Italy. Plant Biosyst, 145: 953-960.

- Venturella, G, Bernicchia, A and Saitta, A. 2007. Contribution to the knowledge of diversity and distribution of lignicolous fungi from Sicily (southern Italy). Bocconea, 21: 291-295. 
- Vizzini, A. 2009. Due nuove combinazioni nel genere Cleistocybe (Basidiomycota, Agaricomycetes), con validazione di Hygrophorus pleurotoides. Micologia e Vegetazione Mediterr, 24: 95-98.

- Vizzini, A, Antonin, V and Noordeloos, M E. 2007. Crinipellis pedemontana sp. nov. (Agaricomycetes), a new basidiomycete from Italy. Mycologia, 99: 786-791.

- Vizzini, A, Consiglio, G, Antonin, V and Contu, M. 2008. A new species within the Gymnopus dryophilus complex (Agaricomycetes, Basidiomycota) from Italy. Mycotaxon, 105: 43-52.

- Vizzini, A, Musumeci, E and Murat, C. 2010. Trichocybe, a new genus for Clitocybe puberula (Agaricomycetes, Agaricales). Fungal Diversity, 42: 97-105.

- Worrall, J J, Anagnost, S E and Zabel, R A. 1997. Comparison of wood decay among diverse lignicolous fungi. Mycologia, 89: 199-219. 